\title{
The Culture Characteristics in Japan's Edo Era and Its Status Change from Subculture to Mainstream
}

\author{
Zhang Haimeng \\ Foreign Languages Department, Tianjin University of Finance and Economics, Tianjin, China \\ Email address: \\ angelmoeru@126.com
}

\section{To cite this article:}

Zhang Haimeng. The Culture Characteristics in Japan's Edo Era and Its Status Change from Subculture to Mainstream. International Journal of Language and Linguistics. Vol. 4, No. 2, 2016, pp. 70-73. doi: 10.11648/j.ij11.20160402.14

\begin{abstract}
The feudalistic culture in Japan reached its peak in Edo Era. Culture in this period gradually became improved and mature in the peaceful development of the society. The cultural subject changed from a few people in the upper class to the amerchants and even the common people. The culture of the ever-growing amerchants displayed great vitality and became the mainstream by surpassing the warrior culture. Respectively representing "the elegant" and "the popular", the warrior culture and the Edo culture, struck a balance, merged with each other and enjoyed the mutual development in their conflict. The Edo culture had a balanced duality from both the exterior and the interior.
\end{abstract}

Keywords: Edo Culture, Characteristics, Status Change, Subculture, Mainstream, Duality

\section{Introduction}

Japan's Edo Era has developed its distinctive and brilliant culture in its duration of over 260 years, evolving itself into a historical phase of special significance in Japanese culture. After the realization of Japan's unification, the culture in this era emerged and gradually changed in the peaceful social development. Its rich content and substantial scale represented the maturity of Japanese culture in certain historical stages. The cultural status, compared to the past, had changed from a few people in the upper class, such as aristocrats and asamurais, to the amerchants ${ }^{\mathrm{i}}$ and even the common people. This thesis aims to analyze the characteristics and the status change of the culture in Edo Era.

\section{The Characteristics in Japan's Edo Culture}

In terms of the postwar research trends, the comments of Edo culture can be sharply divided into the positive and the negative; and various perspectives have provided important prior research to its historical position. To be brief, there are two aspects in general.

(1) The study from the perspective of the national seclusion in Edo Era. There exist the following two different viewpoints in this angle. The Prewar scholars mostly held that the isolation avoided the impact and the adverse influence of the foreign culture, and well safeguarded the unity of Japan. Thus, the unique culture of the Edo Era had been formed. In contrast, the other view believed that Japan's sealing-off culture had completely cut off itself from the exchange and communication with the world, and hindered the modernization of Japan, leading to the stagnation of the social culture.

(2) The analysis from the relationship between the modern culture and the Edo culture. Many scholars in the early postwar period believed that the Edo culture was the dark feudal culture, and the obvious rupture existed between the Edo culture and the Japanese culture after Meiji, especially the post-war Japanese culture. Ever since the 1960s, the academia have raised different voices concerning this problem. They believe modern culture has inherited and promoted the Edo culture. The modern culture after Meiji was based on the Edo culture and the latter incubated the former. Fang Heche, the Japanese scholar, argues in recent years to reappraise the Edo culture and to discover the positive significance of the Edo culture from every aspect. In Edo period, social structure and cultural forms came to get to the peak, presenting a prosperous situation. The traditional natural economy gave birth to the newly emerging commodity economy; and 
under the condition of new economy, social structure and culture form changed correspondingly.

Since the Edo culture emerged in the struggle between the natural economy and the commodity economy, its prosperity and decadence would go in accordance with the trend of social structure and conscious level. Ideology, social structure and all culture levels of literature and art developed in a wavy way due to the conflict between natural economy and commodity economy, which also proved its status and role in the process of the evolution of Japanese culture.

To sum up, the Edo culture at this time had two features. On the one hand, it reached the top of the feudal culture, showing the maturity of the traditional social culture; On the other hand it also displayed the trend of the rise of new culture formed in the commodity economy and the replacement and termination of the traditional social culture. The Edo culture did not give rise to the modern culture directly, but it offered the necessary preparations for the disintegration of the traditional culture, and accelerated the decline of the traditional social culture to a certain extent.

\section{The Status Change}

If not carefully analyzed, the Edo culture can be thought of as the amerchant culture, that is to say the common people's culture, which the author considers a bit biased and one-sided, as a matter of fact, more seriously speaking, concealing the essence of the development of cultural system, since the asamurai culture was impacted, replaced and declining day by day, yet it didn't die out completely and still played an important role in the cultural ecology. In fact, the aristocratic dynasty culture once took on the situation of revival after many years of Shogun beating swords into plowshares, especially in the middle of the Edo Era, giving up the popular literature to resurrect the elegant literary models became the remarkable trend. Strongly influenced by it, some amerchant writers had to "mingle with the men of letters and pose as lovers of culture". To some extent, the Edo culture could be said to inherit and consult the model of the public traditional culture and be impacted by the asamurais society. Only seen from that point, the term "the common people's culture" seemed impossible to include its beginning and the end.

Among the previous theories, Nakanomititosi put forward the theory of "fusing the elegant with the popular" in 1993. "The elegant" represented the public and the asamurais' traditional and elegant temperament and interest; "the popular" referred to the popular world with strong Edo characteristics. In terms of literature, the former were on behalf of the learnedness and refinedness of Chinese poetry and waka, while haikai naturally belonged to the latter. Nakanomititosi claimed the so-called "the elegant" and "the popular" were not isolated, but mutually blended and mixed to form the whole of the Edo culture. That is the real feature of the Edo culture.

Compared with other periods, the culture in this era had many distinctive features. Firstly, it differed from the isolation between the urban and rural areas in ancient times, and it was also distinct from the situation of daimyo separatism in the middle ages. It emerged after the realization of the national unification, gradually changed with the peaceful development of society, and no more followed the mainland culture. In addition, the policy of civil management advocating the management of the country based on Confucianism allowed the people from all walks of life in the whole society to have chances to participate in the creation of the cultural field, from which we can see that the cultural subject and possessors were no longer the upper classes such as the rare aristocrats and asamurais but the amerchants and even the common people.

The social situation brought about the emergence of the national culture, and the culture of national customs with Japanese characteristics became more flourishing. No doubt, the common people from the middle and lower social classes, among whom the new amerchants took the lead and an active part in the activity, from which we can see that the whole literature in the Edo Era had a tendency of the flavor of marketplace literature. All of those formed an important historical and cultural phenomenon - the Edo culture yielded unusually brilliant results because of abundant content and enormous scale and was the maturity of Japanese culture in a certain historical period.

The Edo culture could be divided into two stages, the early "Genroku culture" in the period of Genroku and the latter "Kasei culture" in the period of Bunka and Bunsei, between which the latter was more symbolic. The previous culture, based on the aristocrats and asamurais, gradually displayed the characteristics of cultural infiltration by the common people. For example, the grand occasions such as the New Year, Setsubun, Obon Festival which could only be held in the palace before spreading to the asamurai family little by little, and finally came into the home of the common people. "Seen from the perspective of culture, the feudal culture reached the unprecedented maturity, and the Kabuki, painting, etc with Japanese characteristics all got great achievement. However, the feudal culture was inevitably replaced by the civil culture." "ii The cultural type transformed from the previously rigid aristocratic elite culture to fully creative commercialization. Meanwhile, the new breakthrough had been made by absorbing the essence of the folk culture and art.

Seen from the cultural subject in this period, the Edo culture was developed along the following two principal lines. One was the feudal culture in which the asamurais were the main body; the other was the amerchant culture with the strongest characteristics of the common people. The two were not isolated but mutually infiltrated in their respective development. Since the asamurais were no longer in the chaos caused by war in the period of Muromachi and the State of War, gradually became the parasitic officials in the Shogunate System. Therefore, the asamurai stratum lost their remaining vitality and correspondingly their culturally innovative ability. With their going downhill, the asamurai-based culture was at a standstill.

However, the amerchant culture displayed exuberant vitality with the amerchant stratum growing stronger and stronger so that they attained unprecedented achievement in the field of ideology, literature and art, such literary forms of 
the common people as plays, Ukiyoe, Kabuki, and so on. As Dr. Watujiteturou said, "The scholarship in the Edo Era was created by the Confucians, while the other aspects of literature such as literature and art, dramas, music, painting and etc were created by the amerchants.",iii

The academia mainly distinguish the asamurai culture from the common people's culture from a very harsh perspective and positioned the Edo culture as the common people's culture. This judgment should be the conclusion based on the characteristics of the era's culture bearer. Tudasoukiti claimed in his book Study on the National Thought Embodied in Literature in 1953 that the Edo culture was the time of the common people's culture, which was on the basis of the view point of the traditional culture history. ${ }^{\text {iv }}$ Seen from this perspective, the ancient culture should belong to "the aristocratic culture" while that of the middle ages should be the asamurais culture and that of the recent century in nature should be the common people's culture. Another term "the amerchant culture" was only the prerequisite of the metropolitan culture established in the Edo culture, replacing "the common people" with "the amerchants".

No doubt, with the amerchant class going from strength to strength, the urban modes of life was full of strong flavor of the amerchants, who also replaced the asamurais in the cultural field and played a leading role. Concretely speaking, the following aspects can tell us the details.

(1) The alternation of the real power in Yoshiwara

Yoshiwara, the former social place for such higher asamurais as hatamotos and daimios, changed hands and appearance with the asamurai class going down and the amerchant class going up. Since the financial difficulty in Shogunate resulted directly in the poverty of the asamurais and the shortage of money to squander, Yoshiwara, as the previous sleepless and bustling place, once got into the trouble of closing the door. Later, the newly rich amerchant class took it over and many increasing wealthy merchants gradually possessed its real power. As the spoken part in the Kabuki drama Sukeroku: "the whole power in Yoshiwara was in the hands of the amerchants."

(2) The change of the characteristics of the Kabuki

The accompaniment and performance of the Kabuki changed with the changing mainstream audience, which was also another representative change in the Edo Era. For example, the previously complicated accompaniment and vocal accompaniment usually involved the skilled musicians from the daimios' came to participate in the performance temporarily. However, the declining asamurai stratum couldn't afford the skilled musicians. Till the period of houreki, the Kabuki performers began to cater to the amerchants' musicality and preferences and created the meter beaten together with the bass drum and the snare drum, which was very popular with the audience and set down and spread far and wide.

(3) The timely birth of the Ukiyoe

The term "Ukiyo", coming from Buddhism, literally meant the cycle of people's birth and death and the illusion of the world. The Japanese pronunciation of the word "Ukiyo" is the same as weltschmerz in Japanese. The Japanese society in the middle ages was turbulent; in addition, there was also the influence of the idea of anitya in Buddhism, so the people often called the real world as weltschmerz. Since it came into being in Japanese, "Ukiyo" often contained the meanings of fashion, Gaudything and dissolute life. The change of the concepts about the society and the culture in relation to "Ukiyo" formed the sharp contrast with hereditary and stable official culture. Asairyoui described in his Ukiyo Monogatari as follows, "To live in the present world, we were surrounded by light moon, flying snow flake, sakura, maple leaves, melodious songs, fine wine, all of which made us lose our roots, and showed indifference to the wealth in our presence, lighthearted and carefree, merely like a calabash flowing freely on the water.",

The Ukiyoe, painting the scenes of the society, was a wonderful work of art with unique national characteristics and typical art about the red-light district. The emergence of this colorful estampe greatly promoted the development of the Edo art and formed its most widely used creation.

The Ukiyoe, emerging with the rapid development of the economy and culture for the common people, had a deep influence on the social life and strong vitality. The painters of the Ukiyoe were all the common people and all reflected their temperament and interest in their works. The topics varied a lot, such as the social current affairs, folklores, historical anecdotes, opera scenes, pictures about the classics, and even women's life, battles or scenes about mountains and rivers featured by some painters. Having followed the style of the artistic paintings in the latter half of the $16^{\text {th }}$ century, the Ukiyoe mainly represented the fashion and tastes of the urban bourgeoisie. It could almost serve as the encyclopaedia for the people in the Edo Era to the effect that the tone of the paintings all embodied the thought and feelings of the newly-developing amerchants and the leading role of the amerchant culture.

In this period, many celebrities from the amerchants in the cultural circles made great contribution to the fields of literature and art, such as playwright Santoukyoude, Sikiteisanba, the Confucian Itoujinsai, etc. The playwright Tikamatumonzaemon once said, "The asamurais were not necessarily noble and the amerchants were not necessarily humble", which showed the great improvement in the status of the amerchants.

\section{Conclusion}

The literary men, active in the world as the presenters fusing the elegant with the popular, mostly were aretainers or merchants in the Shogun. They themselves also possessed the dual identities and fulfilled dual social responsibilities. In the "public" world, they played their respective social roles in their own positions. However, once they left that place into their own "private" world, they might fully expressed their own true feelings in accordance with their own preference. However, those cultural forms were not necessarily directly related to their positions and status. The "public" and the "private" possessed by the literary men respectively belonged 
to the two different domains of social identities and graceful temperament and interest, and therefore were clearly treated in a different way.

That was not limited by the literary men. Nisiyamamatunosuke once stated that the Edo culture was "stage name" culture. ${ }^{\text {vi }}$ The "stage name" was a prop when changing from the daily roles to non-daily roles, with the help of which, the people could be ensured freedom and equality in the face of art.

To make a general survey of the various forms of the Edo culture, it is self-evident that there was not only the coexistence of "the elegant" and "the popular", but also the existence of many seemingly contradictory duality structure shown by a lot of situations. For example, there was rigorous asamurai literature as well as joking light fiction literature. The literary men, active in the world as the presenters of fusing the elegant with the popular, also possessed dual identities and fulfilled the dual social responsibilities. The "public" and the "private" roles possessed by the literary men respectively belonged to the two distinct fields of social identity and artistic temperament and interest and were clearly and differently treated. Meanwhile, the two were not completely separated, but the dual coexistence of the balance between the exterior and the interior. Those are the common characteristics of the Edo culture. It was just the ambiguous world of binary mixture that liberated the people from the constraint of the sheer and absolute dualism, which was not only the opposite concepts between justice and evil, victory and failure, freedom and government, as well as happiness and sorrow, but the existence of reconciliation and balance that was specially possessed.

\section{References}

[1] Takaohitohiko, The common people's culture in the recent century, [M]. Tokyo: IWANAMI SHOTEN, 1997.

[2] Nisiyamamatunosuke: The annals of the Edo culture [M]. Tokyo: IWANAMI SHOTEN, 2006.

[3] Katousyuuiti, translated by Ye Weiqu, etc, Study on Japanese culture, [M]. Beijing: Guangming Daily Press, 2000.

[4] Wang Jianmin, History of communications between Chinese and Japanese cultures, Foreign Language Teaching and Research Press, October, 2007.

[5] Wang Xiaoping, Korean literature in Classical Chinese, Tianjin: Tianjin People's Publishing House, August, 2001.

[6] Ye Weiqu, History of Japanese culture, [M].Guilin: Guangxi Normal University Press, January, 2005.

[7] Yosidasinsi, The Mature Edo, Beijing: Peking University Press, May, 2011.

[8] Wang Qing, Introduction to the Recent Japanese Thoughts, Beijing: World Affairs Press, 2006.

[9] Wang Roxi•Qi Xiuli, The Marriage World of Ukiyozousi, Yinchuan: Ningxia people's Publishing House, October, 2005.

[10] Sugiurahikouko, One day as an Edo native, translated by Liu Wei, Xian: Shanxi Normal University Press, November, 2007.

\footnotetext{
i The amerchant refers to a special social class in the Japanese Edo period, which consists mostly of merchants and partly craftsmen and industry workers. It contains two classes, the upper class who have houses and the right to vote for the Chonin officials, while those who haven't are the lower class. They have the power of autonomy in their own place. The middle of the Edo period has witnessed its unique culture.

iiWang Zhongtian: Study on Japanese Confucianism in the Edo Era, China Social Sciences Publishing House, 1994, P1.

iii Watujiteturou, The Though history of Japanese Ethics, Tokyo, Iwanami bunko, 2011:121.

iv From P 53, in the book.

v Itikoteiji, etc, The Big Dictionary of Japanese Classical Literature (Shortened version), Iwanami bunko, 1986:148.

vi Nisiyamamatunosuke, The Records of the Edo Culture, Iwanami bunko, 2006:98.
} 